\title{
The Use of Coffee Husk as Napier Grass Substitution and Its Effect on Madura Cattle Performance
}

\author{
Sudarman A, Listiawan GB, Khodijah L \\ Department of Nutrition and Feed Technology, Faculty of Animal Science, \\ Bogor Agricultural University, Bogor 16680, Indonesia \\ E-mail: a_sudarman@yahoo.com
}

(received 29-07-2019; revised 10-12-2019; accepted 11-12-2019)

\begin{abstract}
ABSTRAK
Sudarman A, Listiawan GB, Khotijah L. 2019. Penggunaan kulit kopi sebagai pengganti rumput gajah pada performa sapi Madura. JITV 24(4): 166-172. DOI: http://dx.doi.org/10.14334/jitv.v24i4.2006

Penelitian ini bertujuan untuk mempelajari kinerja produksi sapi Madura, dengan pemberian kulit kopi sebagai sumber serat pengganti hijauan rumput dalam ransum. Dua puluh ekor sapi Madura jantan umur sekitar 1,5 sampai 2,0 tahun dengan bobot awal 165-190 kg dibagi secara acak menjadi empat macam perlakuan pakan. Pakan yang diberikan setiap perlakuan yaitu R0= konsentrat 90\% + kulit kopi 0\% + rumput gajah 10\%; R1= konsentrat 90\% + kulit kopi 3,33\% + rumput gajah 6,67\%; R2= konsentrat $90 \%$ + kulit kopi 6,67\% + rumput gajah 3,33\%; R3= konsentrat 90\% kulit kopi 10\% + rumput gajah 0\%. Pakan yang diberikan sebesar 3\% bahan kering dari bobot badan. Sapi dipelihara dalam kandang secara individu selama dua bulan. Variabel yang diamati meliputi konsumsi bahan kering, efisiensi pengggunaan pakan, pertambahan bobot badan harian, kecernaan pakan dan keuntungan. Data yang diperoleh dianalisis dengan sidik ragam dari rancangan acak kelompok yang dilanjutkan dengan uji jarak berganda Duncan. Hasil penelitian menunjukkan bahwa konsumsi bahan kering, efisiensi pengggunaan pakan, pertambahan bobot badan harian dan kecernaan pakan sapi pada setiap perlakuan pakan tidak berbeda nyata $(\mathrm{P}>0,05)$. Rataan konsumsi bahan kering dan penambahan berat badan harian untuk R0, R1, R2, dan R3 masing-masing adalah 6,01; 5,84; 5,73 dan 5,62 kg/ekor/hari dan 0,88; 0,87; 0,84 dan 0,93 kg/ekor/hari/hari. Sedangkan rata-rata efisiensi pakan dan kecernaan DM untuk R0, R1, R2, dan R3 masing-masing adalah 14,64, 14,89, 14,65 dan 16,54\% dan 84,82, 84,37, 83,47 dan 83,30\%. Kesimpulannya adalah penggunaan $10 \%$ kulit kopi sebagai sumber serat pengganti rumput gajah dapat digunakan tanpa mengganggu performa sapi Madura dan memberikan nilai IOFC cenderung lebih tinggi sehingga memberikan keuntungan cenderung lebih besar pada program penggemukan.
\end{abstract}

Key words: Kulit Kopi, Pemanfaatan Pakan, IOFC, Performa Sapi Madura, Rumput Gajah

\section{ABSTRACT}

Sudarman A, Listiawan GB, Khotijah L. 2019. The use of coffee husk as napier grass substitution and its effect on Madura cattle performance. JITV 24(4): 166-172. DOI: http://dx.doi.org/10.14334/jitv.v24i4.2006

This research aimed to evaluate the performance of fattened madura cattle fed on coffee husk as a source of fibre to substitute grasses. Twenty Madura steers aged approximately 1.5 to 2.0 years with initial weight of $165-190 \mathrm{~kg}$ were divided randomly into four different experimental diets, namely R $0=90 \%$ concentrates $+0 \%$ coffee husk $+10 \%$ napier grass, $\mathrm{R} 1=90 \%$ concentrates $+3.33 \%$ coffee husk $+6.67 \%$ napier grass, $\mathrm{R} 2=90 \%$ concentrate $+10 \% 6.67 \%$ coffee husk $+3.33 \%$ napier grass, $\mathrm{R} 3$ $=90 \%$ concentrates $90 \%+10 \%$ coffee husk $+0 \%$ napier grass. The feed was given at $3 \%$ body weight of dry mater. The cows were kept in individual pen for two months. Variables measured were dry mater intake, feed efficiency, average daily gain (ADG), digestibility of feed and income over feed cost. Data obtained were analyzed using analysis of variance based on randomized block design followed by Duncan's multiple range test. Results showed that dry matter intake, ADG, feed efficiency and feed digestibility of cattle on each treatment of the feed were not significantly different $(\mathrm{P}>0.05)$. Average of dry matter intake and daily gain for R0, R1, R2, and R3 were $6.01,5.84,5.73$ and $5.62 \mathrm{~kg} / \mathrm{head} / \mathrm{day}$ and $0.88,0.87,0.84$ and 0.93 $\mathrm{kg} / \mathrm{head} /$ day respectively. While the average of feed efficiency and DM digestibility for R0, R1, R2, and R3 were 14.64, 14.89, 14.65 and $16.54 \%$ and $84.82,84.37,83.47$ and $83.30 \%$, respectively. It is concluded that the used of $10 \%$ coffee husk as a source of fibre for substitution of napier grass can be used without negative effect on madura's cattle performances and tend to give higher values of IOFC on fattening program.

Key Word: Coffee Husk, Feed Utilization, IOFC, Madura Cattle Performance, Napier Grass

\section{INTRODUCTION}

Beef as a source of animal protein have a role in fulfilling community nutrition to support the development of Indonesia's human resources. Along with increasing population, income, and increasing public knowledge of the importance of animal protein, demand for beef is also increasing. Direktorat Jenderal 
Peternakan dan Kesehatan Hewan (2017) reported that the Indonesian beef cattle population in 2015 was $15,419,718$ heads and in 2016 became 16,004,097 heads or increased by $1.22 \%$. While, beef production in 2015 was 506,661 showed an increase by $2.28 \%$ from 2016 (518,484 tons). This is an opportunity for farmers to develop their cattle farm business.

Livestock performance and efficient use of feed are the main indicators of the success of a livestock business. To produce cows with good production performance, feed with nutrient content that can meet the livestock production requirements is needed. In the cattle fattening program, feeding concentrates as the main feed with sufficient nutrient content can produce good cattle performance. The addition of Napier grass as a source of fiber is also important because it can be used as a deterrent to the occurrence of metabolic disorders in cattle. Availability of grass as a source of fiber is not always sufficient throughout the year. Forage production is usually high during the rainy season. However, in the dry season many farmers face difficulties in obtaining forage, especially grass because it is scarce and expensive.

Feed sources of fiber other than grass, such as coffee by-product (mainly coffee pulp and husk), can be used as alternative feed when forage is difficult to obtain. Direktorat Jenderal Perkebunan (2016) reported that coffee production in Indonesia was 639305 tons. Widyotomo (2013) reported that every ton of wet fruit will produce $200 \mathrm{~kg}$ of dry coffee pulp. This is potential to be used as fiber source for animal feed during the dry season.

Use of coffee by-products such as pulp and husk as a single feed for livestock is not recommended, due to the presence of antinutrient and certain nutrient deficiencies. Therefore, coffee by-products must be mixed with other feed ingredients when given to livestock. Badarina et al. (2013) reported that coffee husk can be used up to $20 \%$ in the ration after being fermentated by Pleurotus ostreatus. Increasing level of coffee hull addition into concentrate for dairy heifer reduced microbial protein synthesis $0.687 \mathrm{~g} / \mathrm{day}$ for each percentage unit of coffee hull added in the concentrated (de Souza et al. 2010). Reduction in microbial protein synthesis can reduce weight gain in heifers fed coffee hulls. Didana (2014) reported that in beef cattle show a decrease in feed intake and weight gain directly related to the level of coffee pulp in the diet. On the contrary, Nunez et al. (2015) reported that dry coffee pulp in diets could be supplemented to ruminant diets for supporting milk and meat production without any adverse effect on their health.

The purpose of this study was to evaluate the effect of coffee husk use as a substitution for grass in cattle rations on the production performance of cattle and the value of income over feed cost (IOFC).

\section{MATERIALS AND METHODS}

This study was conducted from April to July 2017 in small holder farm at Tegalwaru Village, Ciampea District, Bogor Regency. Proximate analysis of feed was carried out at the Laboratory of Biological Resources and Biotechnology Research Center, Institute for Research and Community Empowerment, Bogor Agricultural University.

In this study 20 male madura cattles about 2 years old with an initial body weight ranged between 169 $186 \mathrm{~kg}$ were used and placed in individual cages equipped with feed and drinking water containers. The feed given were concentrate, coffee husk, napier grass (Pennisetum purpureum) and multivitamins. Drinking water from the well was given ad libitum.

The experimental feeds were made by mixing concentrates, coffee husk and napier grass with a proportion determined for each treatment in each cow feed container.. Before offered, napier grass was chopped using a chopper machine. The compositions of concentrates are presented in Table 1. Price and nutrient contents (based on proximat analysis) of feed used in this experiment were shown in Table 2.

\section{Maintaining experimental animals}

Animals were adapted to experimental feed and environment for two weeks. After that, the cattle were weighed and given dewormer medicine Kalbazen (10$15 \mathrm{ml} /$ head). During experiment weighing of animal were carried out every two weeks. Animals were kept in an intensive fattening program on individual cages, each of which is equipped with food and drinking water containers and maintained for two months. Feeds were given as much as $3 \%$ of cattle body weight on dry matter basis with concentrates and fiber sources ratio of 90:10. The experimental feeds were given at 6:30 a.m., 12:00 a.m, and 19:00 p.m. Feed refusals were weighed in the morning at 6:00 to calculate feed intake. The nutrient content of the experimental feed is presented in Table 3.

\section{Faecal collection}

Faecal collection was carried out at the end of feding trials for seven consecutive days to determine the digestibility of dry matter, crude protein, and crude fiber in each treatment. Each cage was given a barrier so that the collected faeces did not mix for each treatment. The collected faeces were then weighed and taken about $10 \%$ of the total faeces everyday and then dried under the sun as samples. Samples were then stored in plastic bags and labeled. Total samples that have been dried were then put into the oven $60{ }^{\circ} \mathrm{C}$ for 
Table 1. Composition of feed ingredient in concentrate

\begin{tabular}{lc}
\hline \hline Feed ingredient & Proportion (\%) \\
\hline Cassava flour waste & 30 \\
Rice bran & 9 \\
Pollard & 8 \\
DDGS* & 8 \\
Molasses & 11.50 \\
Soy bean meal & 5 \\
Coconut meal & 12.50 \\
Palm oil cake & 9 \\
Soya full fat & 4 \\
Urea & 0.75 \\
NaCl & 0.75 \\
CaCO3 & 1 \\
Premix kalbe** & 0.5 \\
Total & 100 \\
\hline DDGS (Desilles Died
\end{tabular}

*DDGS (Destillers Dried Grain with Solubles)

** Each 5 kg contains: vitamin A 10,000,000 IU, vitamin D 2,000,000 IU, vitamin E 3,000 mg, vitamin B2 5,000 mg, vitamin B12 5,000 mcg, vitamin B1 1,000 mg, vitamin K 1,000 mg, choline chloride 100,000 mg, nicotinamide 7,500 mg, DL-methionine 100,000 mg, foloc acid 500 $\mathrm{mg}$, D-lysine HCL 75,000 mg, ferrous sulfate 25,000 mg, manganese sulfate 50,000 mg, magnesium sulfate 34,000 mg, cupric sulfate 5,000 mg, Ca-d-panthotenate $2,500 \mathrm{mg}$, zinc sulfate $10,000 \mathrm{mg}$, potassium iodice $100 \mathrm{mg}$, antioxidant and carrier q.5. ad $5 \mathrm{~kg}$.

Table 2. Proximate analysis and price of feed ingredients used in this study

\begin{tabular}{lccccccc}
\hline \hline Feed & Price $(\mathrm{Rp})^{*}$ & Ash & CP & EE & CF & NFE & TDN** \\
\hline Concentrate & 3395 & 16.57 & 17.00 & 4.00 & 10.98 & 51.45 & 67.12 \\
Coffee husk & 1381 & 9.20 & 8.22 & 0.58 & 31.62 & 50.38 & 51.57 \\
Napier grass & 3529 & 14.26 & 11.86 & 2.05 & 29.00 & 42.83 & 52.00 \\
\hline
\end{tabular}

Results of laboratory analyzes of Research Center for Biological Resources and Biotechnology of IPB (2017)

*Price based on feed dry matter.

**TDN was calculated according to Hartadi et al. (1980)

Table 3. Nutrient content (\% DM basis) of experimental diets

\begin{tabular}{lcccc}
\hline \multirow{2}{*}{ Nutrients } & \multicolumn{4}{c}{ Treatment Diets* } \\
\cline { 2 - 5 } & $\mathrm{R} 0$ & $\mathrm{R} 1$ & $\mathrm{R} 2$ & $\mathrm{R} 3$ \\
\hline Ash & 16.34 & 16.17 & 16.00 & 15.83 \\
Crude protein & 16.48 & 16.36 & 16.23 & 16.12 \\
Ether extract & 3.81 & 3.75 & 3.71 & 3.66 \\
Crude Fiber & 12.78 & 12.87 & 12.96 & 13.04 \\
NFE & 50.59 & 50.85 & 51.10 & 51.35 \\
TDN & 65.61 & 65.59 & 65.58 & 65.56 \\
E:P ratio & 3.98 & 4.01 & 4.04 & 4.07 \\
\hline
\end{tabular}

$* \mathrm{R} 0=90 \%$ concentrate $+0 \%$ coffee husk $+10 \%$ napier grass, $\mathrm{R} 1=90 \%$ concentrate $+3.33 \%$ coffee husk + napier grass $6.67 \%, \mathrm{R} 2=90 \%$ concentrate + coffee husk $6.67 \%+$ napier grass $3.33 \%$ and R3 $=90 \%$ concentrate $+10 \%$ coffee husk + napier grass $0 \%$. 
48 hours. The samples were then milled and analyzed for the dry matter, crude protein, and crude fiber content.

\section{Experimental design and data analysis}

Experimental design applied was a randomized block design (RBD) with five treatments and five groups of livestock based on body weight as replication. The grouping of livestock in this study were: $165-170$ $\mathrm{kg}, 171-175 \mathrm{~kg}, 176-180 \mathrm{~kg}, 181-185 \mathrm{~kg}$ and $186-190$ $\mathrm{kg}$. Feed treatment applied in this study were: $\mathrm{R} 0=90 \%$ concentrate $+0 \%$ coffee husk $+10 \%$ napier grass, $\mathrm{R} 1=$ $90 \%$ concentrate $+3.33 \%$ coffee husk + napier grass $6.67 \%, \mathrm{R} 2=90 \%$ concentrate + coffee husk $6.67 \%+$ napier grass $3.33 \%$ and $\mathrm{R} 3=90 \%$ concentrate $+10 \%$ coffee husk + napier grass $0 \%$

Data were subjected to analysis of variance (ANOVA) followed by Duncan's multiple range test if there were differences in mean treatment. Variables observed in this study included: dry matter intake, daily body weight gain, efficiency of feed utilization, digestibility of dry matter, crude protein, crude fiber and income over feed cost (IOFC). The IOFC values were obtained by substracting the amount of income obtained from seling of cattle (body weight gain multiplied by price) with the cost of feed.

\section{RESULTS AND DISCUSSION}

\section{Nutrient intakes, weight gain and feed utilization efficiency}

Nutrient intakes, body weight gain and feed efficiency data are shown in Table 4. Nutrient intake is required for the purpose of maintenance and production (growth, milk production and pregnancy). Different fiber sources in the rations had no effect $(\mathrm{P}>0.05)$ on dry matter intake. This may indicated that the rations with fiber sources from coffee husk or napier grass has similar palatability (Table 4). Daily weight gains were also not different $(\mathrm{P}>0.05)$ among the treatments which were in line with the amount of dry matter intake.

Dry matter intake for all treatments has given cattle body weight gain ranging from 0.84 to $0.93 \mathrm{~kg} /$ day. This means that intake of DM at present experiment has been sufficient for cattle in the fattening phase. The average body weight of cattle during the study for R0, R1, R2 and R3 were 206.4, 205.6, 204.6 and 206.1, respectively. Meanwhile percentage of DMI/LW for R0, R1, R2 and R3 are 2.91, 2.85, 2.79, and $2.72 \%$, respectively. According to Kearl (1982) for cattle in tropical region with live weight of $200 \mathrm{~kg}$ and expected weight gain of $0.75-1.00 \mathrm{~kg}$ should have percentage of DMI/LW around 2.7 - 2.8\%. Except R0, other treatments (R1, R2 and R3) were in accordance with those recommended by Kearl (1982).

Experiment with different feed, Rab et al. (2016) showed that Madura cattle fed diet $(85 \%$ concentrate + $15 \%$ soybean pod) with dry matter content of $72.2 \%$, crude protein $14 \%$, crude fibre $17.1 \%$, NFE (nitrogen free extract) $55.8 \%$ and TDN $71 \%$ resulting in dry matter intake higher $(6.92 \pm 0.24 \mathrm{~kg} / \mathrm{head} / \mathrm{day})$ than present experiment. However, it is further reported that daily gain obtained was only $0.73 \mathrm{~kg} / \mathrm{head} / \mathrm{day}$ which was lower than those obtained in the present experiment. This may indicated that the feed quality used in experiment of Rab et al. (2015) was lower than that in the present experiment as their experimental diet had crude protein $14 \%$ and crude fibre $17.1 \%$, on the other hand the experimental diet in this study contained crude protein ranged $16.12-16.48 \%$ and crude fibre ranged 12.78 - 13.04. It may also be concluded that between these two agriculture wastes, coffe husk can be used better as feed ingredient for beef cattle than soybean pod. Coffee husk, in this experiment, had crude protein and crude fibre of 8.22 and $31.62 \%$, respectively, meanwhile soybean pod had crude protein and crude fibre content of 5.5 and $35.4 \%$, respectively (Wiryawan et al. 2017).

Intake of other nutrients in this study had the same pattern as dry matter intake and statistically all were not significantly different $(\mathrm{P}>0.05)$. Crude protein intake of each feed were relatively similar in all treatments which are directly proportional to dry matter intakes. According to Tuwaidan et al. (2015) the crude protein content in feed greatly determines the dry matter intake. Protein requirement, that will affect the intake, vary according to the body size of the animal, its physiological status, management system, feed resources, and expected performance. Among those factors, only feed resources was different in this experiment, but it did not make $\mathrm{CP}$ intake different since $\mathrm{CP}$ content and DM intake of all treatments were not significantly different. Intake of $\mathrm{CP}$ in this experiment ranging from 910 to $990 \mathrm{~g} /$ day exceeded protein requirement for cattle in tropical region with live weight of $200 \mathrm{~kg}$ and expected weight gain of 0.75 - $1.00 \mathrm{~kg}$ suggested by Kearl (1982), i.e., 622 - 690 g/day. According to Sudarman \& Ito (2000) when crude protein offered higher than required, part of that will be converted as heat resulting in higher heat production. This will contribute to heat stress for the animal in hot environment. Thus providing cattle with higher protein diet than their requirement is not efficient in term of physiological and economical concern as the price of protein source feed is high. However, protein 
Table 4. Nutrient intakes and digestibilities, body weight gain and feed efficiency utilization

\begin{tabular}{lcccc}
\hline \hline \multirow{2}{*}{ Parameters } & \multicolumn{4}{c}{ Treatment Diets* } \\
\cline { 2 - 5 } & RO & R1 & R2 & R3 \\
\hline DM Intake (kg/head/day) & $6.01 \pm 0.39$ & $5.84 \pm 0.18$ & $5.73 \pm 1.06$ & $5.62 \pm 0.96$ \\
CP intake (kg/head/day) & $0.99 \pm 0.06$ & $0.96 \pm 0.03$ & $0.94 \pm 0.18$ & $0.91 \pm 0.16$ \\
CF intake (kg/head/day) & $0.78 \pm 0.04$ & $0.75 \pm 0.02$ & $0.74 \pm 0.13$ & $0.72 \pm 0.12$ \\
Daily gain (kg/head/day) & $0.88 \pm 0.20$ & $0.87 \pm 0.19$ & $0.84 \pm 0.23$ & $0.93 \pm 0.27$ \\
Feed utilization efficiency (\%) & $14.64 \pm 2.45$ & $14.89 \pm 2.77$ & $14.65 \pm 3.40$ & $16.54 \pm 2.76$
\end{tabular}

*R0 $=90 \%$ concentrate $+0 \%$ coffee husk $+10 \%$ napier grass, $\mathrm{R} 1=90 \%$ concentrate $+3.33 \%$ coffee husk + napier grass $6.67 \%, \mathrm{R} 2=90 \%$ concentrate + coffee husk $6.67 \%+$ napier grass $3.33 \%$ and R3 $=90 \%$ concentrate $+10 \%$ coffee husk + napier grass $0 \%$

Table 5. Nutrient digestibility (\%) of experimental feed

\begin{tabular}{lcccc}
\hline \hline \multirow{2}{*}{ Nutrients } & \multicolumn{4}{c}{ Treatment Diets* } \\
\cline { 2 - 5 } & R0 & R1 & R2 & R3 \\
\hline Dry matter & $84.82 \pm 0,93$ & $84.37 \pm 0.47$ & $83.47 \pm 3.74$ & $83.30 \pm 2.60$ \\
Crude protein & $87.17 \pm 0.75$ & $86.09 \pm 0.43$ & $84.43 \pm 3.57$ & $84.72 \pm 2.39$ \\
Crude fibre & $69.51 \pm 1.67$ & $67.89 \pm 0.85$ & $67.40 \pm 7.07$ & $65.83 \pm 5.21$ \\
\hline *R0 $=90 \%$.
\end{tabular}

$* \mathrm{R} 0=90 \%$ concentrate $+0 \%$ coffee husk $+10 \%$ napier grass, $\mathrm{R} 1=90 \%$ concentrate $+3.33 \%$ coffee husk + napier grass $6.67 \%, \mathrm{R} 2=90 \%$ concentrate + coffee husk $6.67 \%+$ napier grass $3.33 \%$ and $\mathrm{R} 3=90 \%$ concentrate $+10 \%$ coffee husk + napier grass $0 \%$

Table 6. Income Over Feed Cost (IOFC) of Madura cattle fed ration with different fiber sources

\begin{tabular}{lcccc}
\hline \hline \multirow{2}{*}{ Variables } & \multicolumn{3}{c}{ Treatment Diets* } \\
\cline { 2 - 4 } & $\mathrm{R} 0$ & $\mathrm{R} 1$ & $\mathrm{R} 2$ & $\mathrm{R} 3$ \\
\hline Total weight gain (kg/head) (1) & 51.0 & 50.2 & 48.8 & 53.8 \\
Cattle selling prices (Rp/kg/head) (2) & 65,000 & 65,000 & 65,000 & 65,000 \\
Gross Income (Rp/head) ((1)*(2)), (3) & $3,315,000$ & $3,263,000$ & $3,172,000$ & $3,497,000$ \\
Feed consumption (kg/head) (4) & 348.5 & 338.9 & 332.4 & 326.2 \\
Feed price (Rp/kg) (5) & 3408 & 3337 & 3266 & 3194 \\
Feed cost (RP/head) ((4)*(5)), (6) & $1,187,879$ & $1,130,936$ & $1,085,607$ & $1,041,595$ \\
\hline IOFC (3-6) & $2,127,121$ & $2,132,064$ & $2,086,393$ & $2,455,405$ \\
\hline *R0 $=90 \%$ con
\end{tabular}

$* \mathrm{R} 0=90 \%$ concentrate $+0 \%$ coffee husk $+10 \%$ napier grass, $\mathrm{R} 1=90 \%$ concentrate $+3.33 \%$ coffee husk + napier grass $6.67 \%, \mathrm{R} 2=90 \%$ concentrate + coffee husk $6.67 \%+$ napier grass $3.33 \%$ and R3 $=90 \%$ concentrate $+10 \%$ coffee husk + napier grass $0 \%$

utilization efficiency is not just based on the quantity, but also its quality.

Wiryawan et al. (2017) reported that feeding Madura cattle with complete ration consuming crude protein of 1300 and $800 \mathrm{~g} / \mathrm{head} / \mathrm{day}$ had daily gain of 674 and 570 $\mathrm{g} / \mathrm{head} / \mathrm{day}$. These cattle daily gain is lower than those obtained in present experiment. Hence, what Kearl (1982) had suggested of the protein requirement for cattle in the tropics seem cannot be applied for all breed cattle and all kind of diets.

Eventhough the highest crude fibre content in present experiment was $13.04 \%$ in diet R3, however its 170 crude fiber intake was not different from other treatments. Crude fiber content in this experiment was still in accordance with that of Luthfi et al. (2018) finding that the crude fibre content of ration for Madura cattle should be no more than $15.38 \%$. Above this level will cause intolerant increase in methane production, reduce feed utilization efficiency and further decrease production performance (Luthfi et al. 2018). This is supported by Montenegro et al. (2016) and (Cottle et al. 2011) who reported that high crude fibre in the diet can cause high methane production which contribute to 8 $14 \%$ lost of digestible energy ingested. 
The treatment of feed with different fiber sources did not give a different effect $(\mathrm{P}>0.05)$ on the feed utilization efficiency. This due to the data of dry matter intake and animal body weight gain, the factors that contribute to feed utilization efficiency, were also not significantly different. Feed efficiency utilization values in this study ranged from $14.59-16.36 \%$ (Table 4). Compared to the results of Rab et al. (2016) using Madura cattle with a value of feed utilization efficiency of $9.8 \%$, the values obtained in this study were higher. Feed efficiency can be used as a criterion to determine the quality of feed given to livestock. High efficiency of feed used can be attributed to better nutrient content of the feed so that eventhough animals consume the same amount of feeds but produce better body weight.

\section{Nutrient Digestibilities}

Nutrient digestibilities of the diets used in the presnt experiment are shown in Table 5. Giving different sources of fiber in the ration had no different effect $(\mathrm{P}>$ $0.05)$ on dry matter digestibility. This is due to the composition of feed ingredients and consumption of dry matter from each treatment relatively similar. The digestibility of dry matter in this study ranged from 83.30 to $84.82 \%$ (Table 5). This digestibility values were comparable to the result of Wiryawan et al. (2017) by feeding Madura cattle with complete ration containing $15 \%$ and $30 \%$ soybean pod resulted in DM digestibility of 83 and $83.6 \%$. Umar et al. (2007) reported that madura cattle fed a diet with concentrate and napier grass ratio of $46.5: 53.5$ with a crude fiber content of $21.36 \%$ resulted in a dry matter digestibility value of $65.51 \%$. The higher digestibility of dry matter in this study than that of Umar et al. (2007) because the crude fiber content of feed in this study is lower which was arround $12.9 \%$ (Table 3 ). The higher crude fiber of a feed will cause the digestibility of the feed to be lower.

Crude protein digestibility in the study showed no significant difference $(\mathrm{P}>0.05)$ between treatments. The absence of the influence of different fiber sources on crude protein digestibility because the quantity and quality of crude protein in all treatments are also relatively not different. This shows that feeding with different fiber sources at the level of up to $10 \%$ of experimental diet did not interfere the performance of rumen microbes in degrading crude protein.

The digestibility value of crude protein in this study were quite similar to those of the study reported by Wiryawan et al. (2017) with Madura cattle fed complete ration containing soybean pod of 15 and $30 \%$ with crude protein content of 15.2 and $15 \%$ resulted in crude protein digestibility of 89.4 and $87.0 \%$, respectively, while in the present experiment the crude protein digestibility ranged from $84.43 \%-87.17 \%$. The crude protein content of the feed in this study was somewhat higher, i.e., 16.12 - $16.48 \%$ and TDN was rather low (Table 3) compared to those reported by Wiryawan et al. (2017). According to McDonald et al. (2011) protein digestibility of feed depends on protein quantity and quality in rations and rumen microbial activity. In line with that, Jayanegara et al. (2006) revealed that feeding with high crude protein content activates microbes in the rumen. The number of proteolytic bacteria in the rumen will be high followed by the deamination process which results in increased digestibility of feed organic matter. For rumen bacterial growth high protein supply should be provided with proper energy availability. In present experiment energy (TDN); protein ratio ranged from $3.98-4.07$ and gave daily gain of $0.84-0.93$ $\mathrm{kg} /$ day while the experiment (Wiryawan et al. 2017) energy (TDN) ; protein ratio were 4.49 and 4.55 and gave daily gain of 0.67 and $0.57 \mathrm{~kg} /$ day. Study on the different levels of energy and protein, Li et al. (2014) found that cattle given high energy diet combined with either low or high protein tended to result in higher gain than those fed low energy diet, i.e., 0.74 vs $0.64 \mathrm{~kg} /$ day.

Digestibility of crude fiber in this study also showed no significant difference $(\mathrm{P}>0.05)$. This shows that feeding different fiber sources does not interfere with rumen microbial activity in degrading crude fiber. The digestibility value of crude fiber in the present study tends to be higher than that reported by Zulkarnaen (2017) using Bali cattle fed 30\% concentrate and 70\% fiber sources which yield crude fiber digestibility of $51.09 \%$. Higher crude fiber digestibility value in this study was due to its crude fiber content of only 12.78 $13.05 \%$ (Table 3) lower than that of Zulkarnaen (2017) which used rations with crude fiber content of $28.23 \%$. It is a common knowledge that diet with higher crude fibre content usually has lower digestibility.

\section{Income Over Feed Cost (IOFC)}

Calculation results of Income Over Feed Cost (IOFC) are shown in Table 6. Giving different sources of fiber in feed statistically had no effect $(\mathrm{P}>0.05)$ on IOFC values. This is because body weight gain and feed consumption in all treatments were also not significantly different.

However, numerically that is the important thing in business, the IOFC value of the R3 treatment was higher than those of the other treatments. This is because the price of coffee husk was cheaper than the prices of napier grass so that the cost of feed for R3 treatment becomes cheaper than those of the other treatments. Besides that body weight gain and feed utilization efficiency in R3 treatment were better than those of other treatments which contribute to the higher IOFC value of R3 treatment.

This study showed that $10 \%$ of napier grass (in dry matter) in beef cattle ration can be replaced by equal 
portion of coffee husk dry matter. Indonesia produced 639,305 tons coffee cherry (Direktorat Jenderal Perkebunan 2016) and $20 \%$ of that is waste in form of coffee husk (Widyotomo 2013). Since dry matter content of coffe husk and napier grass are $86.91 \%$ and $14.17 \%$, respectively, thus coffee husk can replace 784,220 tons fresh napier grass. This total amount of coffe husk can be used to feed 3,367,394 heads of beef cattle in 58 days finishing program with the ration of $90 \%$ concentrate and $10 \%$ coffee husk.

\section{CONCLUSION}

Coffee husk at $10 \%$ of the total feed can be used as a source of fiber to replace napier grass use during dry season without disrupting the performance of Madura cattle and producing higher IOFC values, thus giving higher profits to the cattle fattening business.

\section{REFERENCES}

Badarina I, Evvyernie D, Toharmat T, Herliyana EN, Darusman LK. 2013. Nutritive value of coffee husk fermented with Pleurotus ostreatus as ruminant feed. Media Peternakan. 36:58-63.

Cottle DJ, Nolan J V, Wiedemann SG. 2011. Ruminant enteric methane mitigation: a review. Anim Prod Sci. $51: 491-514$.

Didana LD. 2014. A critical review on feed value of coffee waste for livestock feeding. World Sci Res Journals World J Eng Phy Sci. 2:072-086.

Direktorat Jenderal Perkebunan. 2016. Statistik Perkebunan Indonesia Komoditas Kopi 2015-2017. Jakarta (Indones): Direktorat Jenderal Perkebunan-Kementerian Pertanian Republik Indonesia.

Direktorat Jenderal Peternakan dan Kesehatan Hewan. 2017. Statistik Peternakan dan Kesehatan Hewan 2017. Jakarta (Indones): Direktorat Jenderal Peternakan dan Kesehatan Hewan-Kementerian Pertanian RI.

Jayanegara A, Tjakradidjaja AS, Sutardi T. 2006. Fermentabilitas dan kecernaan in vitro ransum limbah agroindustri yang disuplementasi kromium organik dan anorganik. Media Peternakan. 29:54-62.

Kearl LC. 1982. Nutrient Requirements of Ruminants in Developing Countries. Logan (US): Utah State University.
Li L, Zhu Y, Wang X, He Y, Cao B. 2014. Effects of different dietary energy and protein levels and sex on growth performance, carcass characteristics and meat quality of F1 Angus $\times$ Chinese Xiangxi yellow cattle. J Anim Sci Biotechnol. 5:21.

Luthfi N, Restitrisnani V, Umar M. 2018. The Optimation of Crude Fiber Content of Diet for Fattening Madura Beef Cattle to Achieve Good A:P Ratio and Low Methane Production. IOP Conf Ser Earth Environ Sci. 119:012056.

McDonald P, Edwards RA, Greenhalgh JFD, Morgan CA, Sinclair LA, Wilkinson RG. 2011. Animal Nutrition. 7th ed. London (UK): Prentice Hall.

Montenegro J, Barrantes E, DiLorenzo N. 2016. Methane emissions by beef cattle consuming hay of varying quality in the dry forest ecosystem of Costa Rica. Livest Sci. 193:45-50.

Rab S, Priyanto R, Fuah AM, Wiryawan IKG. 2016. Daya dukung dan efisiensi produksi sapi Madura dengan pemanfaatan limbah kacang kedelai. JIPTPHP. 4:340344 .

Souza AL de, Garcia R, Cabral L da S, Pereira MLA, Valadares RFD. 2010. Coffee hull in the diet of dairy heifers: nitrogen balance and microbial protein synthesis. Rev Bras Zootec R Bras Zootec. 39:1141-1145.

Sudarman A, Ito T. 2000. Effects of Dietary Protein Sources and Levels on Heat Production and Thermoregulatory Responses of Sheep Exposed to a High Ambient Temperature. Asian-Australasian J Anim Sci. 13:15231528 .

Tuwaidan NWH, Waani MR, Rustandi, Malalantang SS. 2015. Konsumsi dan kecernaan jerami jagung manado kuning dan jerami jagung hibrida Jaya 3 pada sapi PO. ZOOTEC. 35:328.

Widyotomo S. 2013. Potensi dan teknologi diversifikasi limbah kopi menjadi produk bermutu dan bernilai tambah. In: Rev Penelit Kopi dan Kakao. Jember (Indones): Pusat Penelitian kopi dan Kakao; p. 63-80.

Wiryawan KG, Saefudin A, Fuah AM, Priyanto R, Khotijah L, Suharti S. 2017. Fermentation Characteristics and Nitrogen Retention of Madura Cattle Fed Complete Rations Containing Soybean Pod and By-Products. Media Peternakan. 40:28-34.

Zulkarnaen A. 2017. Kecernaan nutrien dan performa sapi Bali yang diberi ransum hijauan tinggi dan disuplementasi sabun kalsium minyak kedelai (Thesis). Bogor (Indones): IPB University. 